\title{
Comparison analysis of micropile and slab foundation for transmission tower
}

\author{
WANG Hua Juan ${ }^{1,}$ a \\ ${ }^{1}$ Shandong Electric Power Engineering Consulting Institute corp., Ltd., Jinan 250013, China \\ awanghuajuan@sdepci.com
}

\begin{abstract}
Keywords: transmission tower; slab foundation; micropile; comparison analysis
Abstract. Transmission tower is constructed quickly in China and the foundation of tower should be studied for economical and security reasons. A simplified analytical is presented for the mechanism of the new micropiles foundation, which have many advantages in design and construction stage, such as accurate calculation, loading transfer clearly, convenient installation and cost reduction. Slab foundation is a traditional type and building as a main way in the past fifty years. By mechanism analysis, some disadvantages had been achieved and the kind of foundation is inadaptable in many engineering site. By a real project, the design plan and construction quantities had been drawn and comparison analysis had been conducted. Some meaningful conclusions proposed which can provide a reference for similar project.
\end{abstract}

\section{Introduction}

With the rapid development of national economy of China, power infrastructure investment is increasing in recent years. At present, the main form of steel tower foundation in soil is extended slab foundation. Extended foundation design and calculation method is simple, but the kind of foundation have more disadvantages, such as the basic volume and large excavation quantities, larger covering area, heavier construction machines and handling difficulty.

Transmission towers can be supported by pile foundation instead of slab foundation and micropiles are introduced into this kind of structure in recent years. The micropile, which has a diameter of less than $300 \mathrm{~mm}$ and is five to ten meters in length, may be effectively used to resist vertical and uplift forces. The overturning of power-transmission towers due to wind may also cause uplift forces [1,2]. When the micropile is used to reinforce foundations, the compressive force is loaded on the micropile. Featherless, the micropile not only has several advantages for use with compressive forces, but also can resist high uplift forces due to the high resistance of the steel bar, steel pipe or rebar inside the micropile. The foundation layout of micropile used in transmission tower is shown as figure 1 .

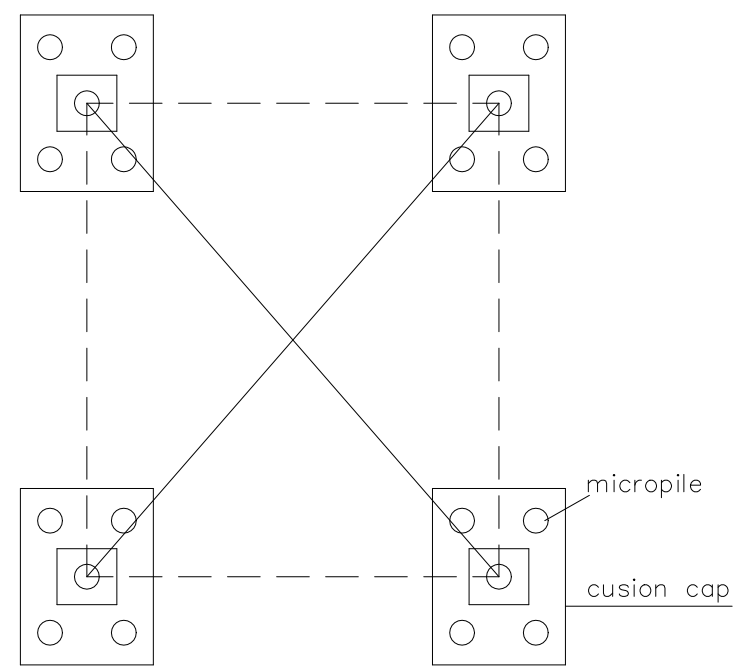

Fig. 1 The micropile foundation layout plan of transmission tower 
Since the diameter of the micropile is small, the frictional area of the micropile is over 100 times larger than the cross sectional area of the micropile. Therefore, high uplift capacity is expected from micropiles, the same as compress capacity.

\section{Mechanism and construction of micropile}

Micropile foundation had been produced firstly by Tongji University in 1981 and applied to some projects. Based on many engineering practices, the mechanism of micropile had been summarized, design parameters of cement paste, steel reinforcement cage and bearing capacity calculation had been provided.

By previous researches[3,4], the small-diameter pile can better constructed in transmission tower foundation: (1) micropile construction machinery is simple, can use small drilling machine to pore-creating and strong adaptability to the surrounding environment; (2) the hole of pile is smaller and can be used for all kinds of soil except for pebble bed and do not produce additional stress, noise and vibration caused by the construction; (3) secondary grouting technology can be used in micropile, which increased the superficial area of pile and shearing and compress strength of pile side earth by cement paste injected into around soil layer, the uplift and loading capacity are improved effectively. (4) the micropile can be arranged neatly and inclined pile can be designed easily. The foundation section of micropile used in transmission tower is shown as figure 2.

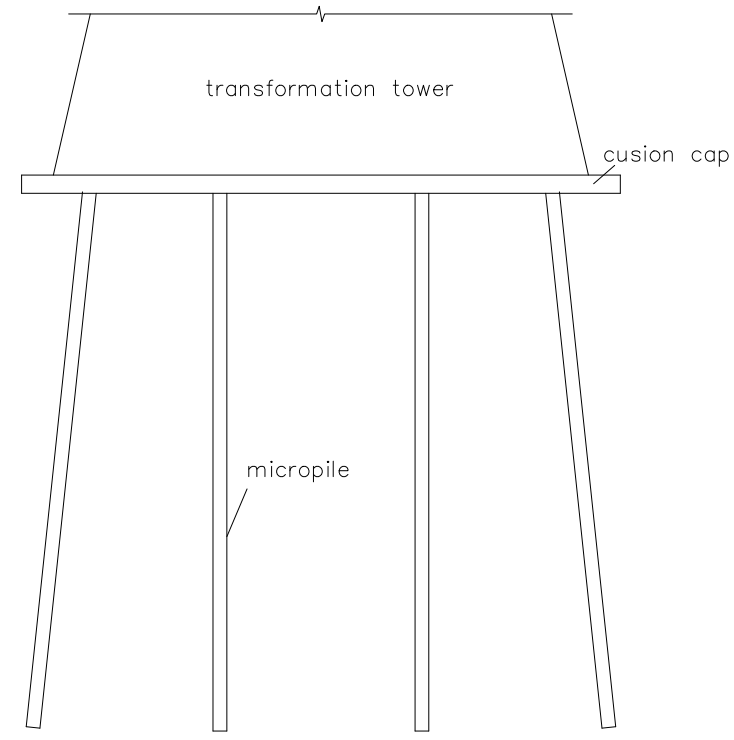

Fig.2 The micropile foundation layout section of transmission tower

Borehole of micropile is drilled firstly using minitype drill machine and the borehole had been cleaned when the depth has achieved designed elevation, then the steel reinforcement cage be put into the hole. Secondary grouting pipe be strapped before the cage sunk, smaller hole had been penetrated on the pipe at regular intervals and closed off with seal material outside of pipe to prevent cement paste into the pipe. After gravel putted into the hole up to the top, cement paste are injected by mud jack until mud spillover. Secondary grouting will be carry out after initial set, one day usually. Higher press mud jack is used for secondary grouting and the seal material outside of secondary grouting pipe can be break through and cement paste be infused into pile [5]. At last the micropile can be formed almost with diameter no less than $250 \mathrm{~mm}$.

\section{Characteristic of slab foundation}

Raft foundation is consisted of base plate and beam and form a whole structure. When building loading is larger, the foundation bearing capacity is weak, concrete baseboard is often used to bear loading of building, that is slab raft. Slab foundation has better integrity and can be a very good 
resistance to uneven settlement of foundation. The slab foundation can be constructed by united the independent foundation under column or strip foundation beam, then the whole bottom board below is pouring. Raft foundation is divided into plate type raft and beam type raft, plate type raft can be extended by local thickening raft; Beam type raft can be designed for two forms, that are under or up the flat. Generally uneven ground capacity or the foundation weak the raft foundation is achieved, at the same time, the raft foundation depth is shallow, even can be buried no more than two meters. The slab foundation layout used in transmission tower is shown as figure 3 .

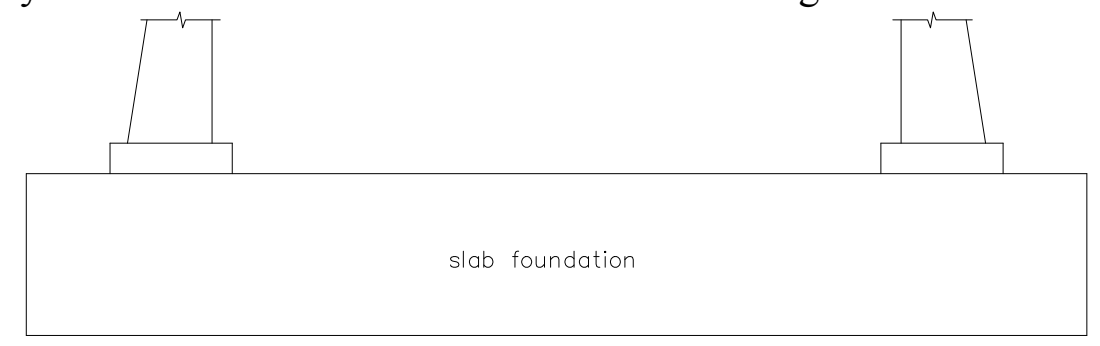

Fig. 3 The slab foundation layout section

The relations between the upper structure, foundation and ground is mutual influence and mutual restriction relations. The calculation method of three segment worked as a whole based on an assumption, which is the upper structure and foundation, foundation and ground connection interface deformation coordination of the whole system in static equilibrium. For the foundation, by considering the contribution of the upper structure, reduce the overall bending deformation and internal force, and gain more economic effect; For the upper structure, due to considering the deformation caused by deformation of foundation, the secondary stress deformation will lead to the upper structure, considering the secondary stress, structure will be more secure.

\section{Comparison analysis of slab and micropile foundation}

Large-span tangent tower is selected for studied using two differential kinds of foundations, micropile foundation and slab foundation. According to a real project in Dongying city, calculation and comparison analysis are conducted and shown as follows:

(1) calculation results of micropile foundation: the loading of upper structure is $2400 \mathrm{kN}$ and 12 micropiles are needed. The diameter of micropile is $250 \mathrm{~mm}$ and cement mortar strength is C20. Four cushion cap are designed in this project and every cushion cap has 3 micropiles, the layout plan is shown as figure 4 .

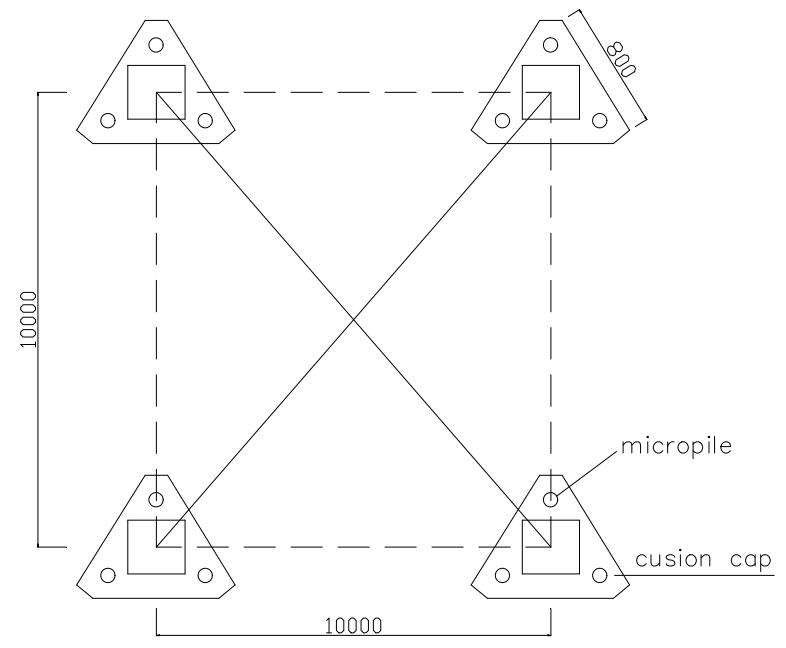

Fig.4 The micropile plan of a real project

(2) slab foundation: the raft is designed as a square plate with its dimensions is $8 \mathrm{~m}$ and the buried depth is $4 \mathrm{~m}$, which is taken uplift load into account. The thickness of plate is $1 \mathrm{~m}$ and casting with concrete strength grade $\mathrm{C} 30$. The section of slab foundation is shown as figure 5 .

The comparison of bill of quantities is shown as Table 1. By the data of table 1, the quantities of concrete and steel of micropile foundation is smaller than reinforced concrete slab foundation, only 
little of cement paste and gravel are needed. On the whole, the micropile foundation is superior to slab foundation and get more and more used in engineering.

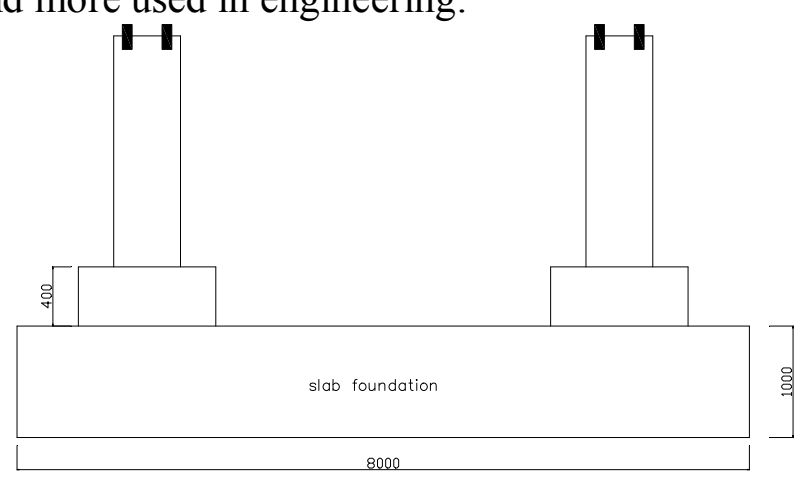

Fig.5 The slab foundation and short column section of a real project

Table 1 Quantities comparison

\begin{tabular}{|c|c|c|c|c|}
\hline Foundation type & $\begin{array}{c}\text { Concrete } \\
{\left[\mathrm{m}^{3}\right]}\end{array}$ & $\begin{array}{c}\text { Cement paste } \\
{\left[\mathrm{m}^{3}\right]}\end{array}$ & $\begin{array}{c}\text { Gravel } \\
{\left[\mathrm{m}^{3}\right]}\end{array}$ & $\begin{array}{c}\text { Steel } \\
{\left[\mathrm{m}^{3}\right]}\end{array}$ \\
\hline micropile & 3.66 & 13.72 & 5.8 & 1944.9 \\
\hline slab & 26.45 & 0 & 0 & 2109.7 \\
\hline
\end{tabular}

\section{Conclusions}

By comparison analysis, the advantages and disadvantages of micropile and slab foundation for transmission tower had been discussed. Based on a real project, the quantities of two kind of foundation had been achieved. From these analysis, micropile has shown the superiority in transmission tower foundation and can be popularization and application in more and more transmission project.

\section{References}

[1] K. N. Osama and A. S. Alawneh, Micropile technique to control upward movement of lightweight structures over expansive soils, Geotechnical and Geological Engineering vol.22 (2004), p. 89

[2] A. Awad and A. Ayoub, Ultimate uplift capacity of vertical and inclined pile in cohesionless soil, Proceeding of the 5th International Conference on Soil Mechanic and Foundation Engineering, Vol. 1 (1976), Budapest, Hungary, p. 221.

[3] B. C. Chattopadhyay and P. J. Pise, Uplift capacity of piles in sand, Journal of Geotechnical Engineering, Vol. 112(1986), No. 9, p. 888

[4] B. K. Dash and P. J. Pise, Effect of compressive load on uplift capacity of model pile, J. Geotech. Geoenv. Eng., ASCE, Vol. 129 (2003), No.11, p. 987

[5] A. Misra and C. Chen, Analytical solution for micropile design under tension and compression, Geotechnical and Geological Engineering, Vol. 22 (2004), p. 199. 